\title{
Correction to: Energy costs vs. carbon dioxide emissions in short-term production planning
}

\author{
A business case study
}

\author{
Andreas Dellnitz ${ }^{1}$ (D) - Damian Braschczok ${ }^{1} \cdot$ Jonas Ostmeyer $^{1} \cdot$ Markus Hilbert $^{1}$. \\ Andreas Kleine ${ }^{1}$
}

(c) The Author(s) 2021

\section{Correction to: Journal of Business Economics (2020) 90:1383-1407 https://doi.org/10.1007/s11573-020-01000-1}

The article "Energy costs vs. carbon dioxide emissions in short-term production planning, written by Andreas Dellnitz, Damian Braschczok, Jonas Ostmeyer, Markus Hilbert, Andreas Kleine, was originally published Online First without Open Access. After publication in volume 90, issue 9, page 1383-1407 the author decided to opt for Open Choice and to make the article an Open Access publication. Therefore, the copyright of the article has been changed to (C) The Author(s) 2021 and the article is forthwith distributed under the terms of the Creative Commons Attribution 4.0 International License, which permits use, sharing, adaptation, distribution and reproduction in any medium or format, as long as you give appropriate credit to the original author(s) and the source, provide a link to the Creative Commons licence, and indicate if changes were made. The images or other third party material in this article are included in the article's Creative Commons licence, unless indicated otherwise in a credit line to the material. If material is not included in the article's Creative Commons licence and your intended use is not permitted by statutory regulation or exceeds the permitted use, you will need to obtain permission directly from the copyright holder. To view a copy of this licence, visit http://creativecommons.org/licenses/by/4.0/.

The original article has been corrected.

Open Access This article is licensed under a Creative Commons Attribution 4.0 International License, which permits use, sharing, adaptation, distribution and reproduction in any medium or format, as long as

The original article can be found online at https://doi.org/10.1007/s11573-020-01000-1.

Andreas Dellnitz

andreas.dellnitz@fernuni-hagen.de

1 FernUniversität in Hagen, Chair of Operations Research, P.O. Box 940, 58084 Hagen, Germany 
you give appropriate credit to the original author(s) and the source, provide a link to the Creative Commons licence, and indicate if changes were made. The images or other third party material in this article are included in the article's Creative Commons licence, unless indicated otherwise in a credit line to the material. If material is not included in the article's Creative Commons licence and your intended use is not permitted by statutory regulation or exceeds the permitted use, you will need to obtain permission directly from the copyright holder. To view a copy of this licence, visit http://creativecommons.org/licen ses/by/4.0/.

Publisher's Note Springer Nature remains neutral with regard to jurisdictional claims in published maps and institutional affiliations. 